\title{
Energy output reduction and surface alteration of quartz tips following Er:YAG laser contact irradiation on soft and hard tissues in vitro
}

\author{
Taichen LIN¹, Rie KAWAMURA², Akira AOKI ${ }^{1}$, Shizuko ICHINOSE ${ }^{3}$, Koji MIZUTANI' ${ }^{1}$, Yoichi TANIGUCHI ${ }^{1}$, \\ Toru EGURO ${ }^{4}$, Norihito SAITO ${ }^{5}$ and Yuichi IZUMI ${ }^{1}$ \\ ${ }^{1}$ Department of Periodontology, Graduate School of Medical and Dental Sciences, Tokyo Medical and Dental University, 1-5-45 Yushima, Bunkyo-ku, \\ Tokyo 113-8549, Japan \\ ${ }^{2}$ School of Dentistry, Tokyo Medical and Dental University, 1-5-45 Yushima, Bunkyo-ku, Tokyo 113-8549, Japan \\ ${ }^{3}$ Research Center for Medical and Dental Science, Tokyo Medical and Dental University, 1-5-45 Yushima, Bunkyo-ku, Tokyo 113-8549, Japan \\ ${ }^{4}$ Private practice, Gyoda city, Saitama, Japan \\ ${ }^{5}$ Photonics Control Technology Team, Advanced Photonics Technology Development Group, RIKEN Center for Advanced Photonics, Riken, 2-1 \\ Hirosawa, Wako, Saitama 351-0198, Japan \\ Corresponding author, Akira AOKl; E-mail: aoperi@tmd.ac.jp
}

Though the Er:YAG laser (ErL) has been used in periodontal therapy, the irradiated tip damage has not been studied in detail. In this study, the change in the energy output, surface morphology, and temperature of quartz tips was evaluated following contact irradiation. Soft tissue, calculus on extracted human teeth, and porcine bone were irradiated by ErL for $60 \mathrm{~min}$ at 14.2 or $28.3 \mathrm{~J} /$ $\mathrm{cm}^{2} /$ pulse and $20 \mathrm{~Hz}$ with or without water spray. The energy output ratio declined the most in the calculus group, followed by the bone and soft tissue groups with and/or without water spray. Carbon contamination was detected in all groups, and contamination by $\mathrm{P}, \mathrm{Ca}$, and/or other inorganic elements was observed in the calculus and bone groups. The rate of energy output reduction and the degree of surface alteration/contamination is variously influenced by the targeting tissue, temperature elevation of the tip and water spray.

Keywords: Er:YAG laser, Contact tip, Energy output, SEM-EDS, Temperature

\section{INTRODUCTION}

The Er:YAG laser (ErL), which emits at 2,940 nm, is very useful for dental treatment because it can effectively ablate both soft and hard tissues ${ }^{1-3)}$ with minimal thermal damage due to its high absorbability in both water ${ }^{4)}$ and hydroxyapatite ${ }^{5)}$. The ErL treatment is advantageous because it causes less pain, vibration, and discomfort compared to conventional mechanical methods ${ }^{6}$. In addition, the antibacterial and detoxifying effects as well as the biological effects of the ErL may improve the wound healing of treated $\operatorname{sites}^{7-12)}$. The ErL applications in dental treatments such as operative dentistry ${ }^{13-16)}$, pediatric dentistry ${ }^{17,18)}$, endodontics ${ }^{19-21)}$, periodontics ${ }^{22-29)}$, and oral surgery ${ }^{30,31)}$ have increased in recent years. Furthermore, the use of ErL has also been proposed in implant therapy applications such as the implant placement procedure as well as treatment of peri-implantitis ${ }^{32-37)}$.

On ErL irradiation, two irradiation modes are available: non-contact and contact modes ${ }^{38}$. In the non-contact mode, the laser beam is delivered without a contact tip, and a red diode laser, which is released coaxially from the handpiece, is utilized for spot guidance. However, laser irradiation in non-contact mode is difficult to precisely deliver due to the lack of tactile feedback during operation. In contrast, in the contact mode, the laser irradiation can be precisely transmitted on the target tissue by a specially designed contact tip mounted on the handpiece because of the tactile sensation provided by the contact. Therefore, the contact irradiation mode of the ErL is primarily performed in dental treatment. However, the contact surface of tips will get damaged during irradiation, resulting in a gradual reduction of the energy output. Previous studies demonstrated that the energy output reduction from contact tips was related with both the damage to the tip and the presence of contaminants on the contact surface ${ }^{39)}$.

Generally, two types of contact tips, quartz or sapphire crystal rods, are utilized for ErL, and the quartz tip appears to be less resistant than the sapphire tip $^{40)}$. In periodontal usage, ErL is irradiated on various tissues such as the root surface with subgingival calculus, gingiva, and bone tissue, and the curved type tips made of quartz crystal are clinically useful for various applications including insertion into periodontal pockets. So far, however, there have been no detailed studies investigating the changes in the quartz tip after contact usage in periodontal applications.

Therefore, the present in vitro study evaluates the energy output reduction, surface alteration, and temperature change of the quartz tip following ErL contact irradiation on soft and hard periodontal tissues.

Color figures can be viewed in the online issue, which is available at J-STAGE.

Received Jan 21, 2015: Accepted Aug 11, 2015

doi:10.4012/dmj.2015-020 JOI JST.JSTAGE/dmj/2015-020 


\section{MATERIALS AND METHODS}

\section{Laser system and samples}

The ErL device employed was a pulsed Er:YAG laser (Erwin AdvErl ${ }^{\mathrm{TM}}$, wavelength 2,940 nm, pulse width $250 \mu \mathrm{s}$, J. Morita Mfg, Kyoto, Japan). This laser system utilizes an optical fiber delivery system with a contact handpiece.

In the present study, sixty-two unused quartz contact tips made of synthetic fused silica with a diameter of $600 \mu \mathrm{m}$ and flat end were employed (no. C600F). The following samples were used for irradiation: 1) chicken gizzard (simulating gingival soft tissue), 2) subgingival calculus on extracted human teeth, and 3) alveolar bone of porcine mandible. Periodontally diseased teeth with subgingival calculus had been previously collected from patients who went to the Dental Hospital, Tokyo Medical and Dental University, and private dental practices, after obtaining informed consent, and they were stored in our department in saline solution at $4^{\circ} \mathrm{C}$ after extraction. The use of human teeth was approved by the Ethics Committee of the Faculty of Dentistry, TMDU (no. 967).

\section{Experiment 1: Laser irradiation and energy output measurement}

Six tips out of the 30 remained unused as a control group, and six tips were used in each of the four experimental groups: 1) soft tissue group without water spray [soft tissue $\mathrm{W}(-)$ ], 2) soft tissue group with water spray [soft tissue $W(+)$ ], 3) subgingival calculus group with water spray [calculus $\mathrm{W}(+)$ ], and 4) porcine alveolar bone group with water spray [bone $\mathrm{W}(+)]$.

In the soft tissue $\mathrm{W}(-)$ and $\mathrm{W}(+)$ groups, chicken meat was irradiated by ErL for 60 min without or with water spray (approximately $14 \mathrm{~mL} / \mathrm{min}$ water and $3.2 \mathrm{~L} /$ min air, $75 \mathrm{kPa}$ air pressure) at the energy output of 40 $\mathrm{mJ} /$ pulse (panel setting of $70 \mathrm{~mJ} /$ pulse, energy density of $14.2 \mathrm{~J} / \mathrm{cm}^{2} /$ pulse) and the pulse rate of $20 \mathrm{~Hz}$, using a freehand technique with the tip gently in contact and perpendicular to the surface without applying excessive contact pressure.

In the calculus $\mathrm{W}(+)$ group, approximately 50 extracted human teeth with subgingival calculus were used, and irradiation was performed for $60 \mathrm{~min}$ with water spray at $40 \mathrm{~mJ} /$ pulse (panel setting of $70 \mathrm{~mJ} /$ pulse, energy density of $14.2 \mathrm{~J} / \mathrm{cm}^{2} /$ pulse) and $20 \mathrm{~Hz}$ with the tip gently in contact and oblique to the root surface at a $30^{\circ}$ angle. After the calculus was completely removed from the tooth surface, a new tooth was employed for continuous irradiation to calculus.

In the bone $\mathrm{W}(+)$ group, porcine mandibular alveolar bone was irradiated for $60 \mathrm{~min}$ at $80 \mathrm{~mJ} /$ pulse (panel setting of $135 \mathrm{~mJ} /$ pulse, energy density of $28.3 \mathrm{~J} / \mathrm{cm}^{2} /$ pulse) and $20 \mathrm{~Hz}$ with water spray with the tip gently in contact and perpendicular to the bone surface.

The energy output in each group was selected according to the level actually used for each treatment in a clinical setting. The irradiation was performed along a line for meat and bone ablation and in a sweeping motion for calculus removal. The energy output was measured by a power meter (Field Master ${ }^{\mathrm{TM}}$ and LM-P10i, Coherent, Santa Clara, CA, USA) before irradiation, after 1,3 and $5 \mathrm{~min}$ of irradiation, and then every $10 \mathrm{~min}$ until $60 \mathrm{~min}$. The distance between the tip and the laser sensor was set at $35 \mathrm{~mm}$ during measurement. The energy output was measured as the mean of approximately $3 \mathrm{~s}$ (60 shots), and the measurement was performed in quintuplicates for each tip. The five data points were averaged, and the average was determined as the representative value for each tip at each time point.

\section{Morphological analysis of the contact surface}

The contact surface of the tips was observed by optical stereomicroscopy (VH-7000 ${ }^{\circledR}$, Keyence, NJ, USA) and scanning electron microscopy (SEM) (S-4500, Hitachi, Tokyo, Japan). Prior to evaluation, the tip surface was rinsed with water spray and dried by an air syringe without any other cleaning or treatment. Then, following sputter coating with osmium plasma at a thickness of 4 $\mathrm{nm}$, the SEM secondary electron image of the tip contact surface was taken at an accelerating voltage of $15 \mathrm{kV}$.

\section{Compositional analysis of the contact surface}

The chemical compositional analysis of the contact surface was performed by SEM energy dispersive X-ray spectroscopy (SEM-EDS) using an energy-dispersive X-ray microanalyzer (EMAX-7000 ${ }^{\circledR}$ Horiba, Kyoto, Japan). The contact surface of the unused and used quartz tips was examined for the presence of silicon ( $\mathrm{Si}$ ), oxygen $(\mathrm{O})$, carbon $(\mathrm{C})$, phosphorus $(\mathrm{P})$, calcium $(\mathrm{Ca})$, sodium $(\mathrm{Na})$, and magnesium $(\mathrm{Mg})$ under $0.2 \mathrm{nA}$ and 15 $\mathrm{kV}$ for $100 \mathrm{~s}$ using characteristic X-rays of $\mathrm{SiK} \alpha, \mathrm{OK} \alpha$, $\mathrm{CK} \alpha, \mathrm{PK} \alpha, \mathrm{CaK} \alpha, \mathrm{NaK} \alpha$, and $\mathrm{MgK} \alpha$, respectively. The original constituents of quartz are considered to be $\mathrm{Si}$ and O. Mapping analysis was used to determine the type and distribution of debris and microparticles attached on the contact surface using 2,000 times magnification in SEM. Furthermore, to determine the elements on the surface, SEM-EDS area analysis was performed on a $400 \times 400 \mu \mathrm{m}$ area in the center of the surface under 100 times magnification in SEM, which covers almost the entire tip surface.

\section{Experiment 2: Measurement of the temperature change of the contact tip}

The temperature change of the contact tip during irradiation was evaluated. In total, 32 unused tips were used, and four tips were assigned to each of the eight experimental groups: 1) no tissue group without water spray [no tissue $\mathrm{W}(-)$ ], 2) no tissue group with water spray [no tissue $\mathrm{W}(+)$ ], 3) soft tissue group without water spray [soft tissue $\mathrm{W}(-)$ ], 4) soft tissue group with water spray [soft tissue $\mathrm{W}(+)$ ], 5) subgingival calculus group without water spray [calculus $\mathrm{W}(-)], 6$ ) subgingival calculus group with water spray [calculus $\mathrm{W}(+)], 7$ ) porcine alveolar bone group without water spray [bone W(-)], and 8) porcine alveolar bone group with water spray [bone $\mathrm{W}(+)$ ]. The irradiation parameters 
employed in experiment 1 were used for this experiment. However, in experiment 2, the irradiation manner was changed, i.e., during irradiation, the contact tip was fixed for temperature measurement, and the targeting tissues were handled and moved by hand simulating experiment 1 . The irradiation time was set as $3 \mathrm{~min}$ for each group. In the no tissue W(-) and W(+) groups, only ErL emission was performed without or with water spray, respectively.

During irradiation, an infrared thermal imaging camera (InfRec R500 series, Nippon Avionics, Tokyo, Japan) was used for temperature measurement of the contact tips. This equipment is composed of an infrared detector and an image display, and it was attached to a personal computer for recording the thermal images. The range of temperature measurement is $-40^{\circ} \mathrm{C}$ to $500^{\circ} \mathrm{C}$, the temperature sensitivity is $0.03^{\circ} \mathrm{C}$, and the accuracy of the temperature measurement is $\pm 1^{\circ} \mathrm{C}$. Fifteen thermal images were recorded every second. After recording thermal images of the lateral surface of the tip end during irradiation, one thermal image was selected out of every fifteen thermal images as the representative temperature at each second. The temperature readings were produced from the thermo-graphic patterns on the monitor, and the average temperature of the area in the tip end was calculated at $1,3,10,30 \mathrm{~s}, 1 \mathrm{~min}$, and 3 min using the 0.9 emissivity of silicon resin, which is the material of the lateral surface of the tips. Finally, the average of the temperature of four tips was determined as the representative value for each group at each time point.

\section{Statistical analysis}

The percentage of measured energy output of the used tip relative to that of the unused tip was calculated and discussed here as the energy output $(n=6)$. The differences in the energy output among the groups at each time point were analyzed by one-way factorial analysis of variance (ANOVA) followed by the Tukey-Kramer posthoc test. Similarly, the differences in the concentration of $\mathrm{Si}, \mathrm{O}, \mathrm{Si}+\mathrm{O}$, and $\mathrm{C}$ among the groups were analyzed by applying one-way factorial ANOVA followed by the Tukey-Kramer post-hoc test. The difference in the total amount of temperature elevations among each group was analyzed by two-factor ANOVA followed by $t$-test with Bonferroni correction. The statistical significance was determined at a $p$-value less than 0.05 using statistical software (StatView 5.0, SAS Institute, Cary, NC, USA and SPSS ${ }^{\circledR}$ version 19.0, SPSS, Chicago, IL, USA).

\section{RESULTS}

Changes in energy output and energy output ratio of all the irradiation groups over time

In the soft tissue W(-) and $\mathrm{W}(+)$ groups, most of the tips exhibited a gradual, continuous reduction of energy output over time and finally exhibited a minimal reduction to $37.7 \mathrm{~mJ}(94.3 \%)$ and $36.5 \mathrm{~mJ}(91.4 \%)$ on average for the $\mathrm{W}(-)$ and $\mathrm{W}(+)$ groups, respectively, after 60-min irradiation from $40 \mathrm{~mJ}$ initially (Figs. 1 and 2).
The soft tissue $\mathrm{W}(+)$ group showed a slightly higher reduction than the $\mathrm{W}(-)$ group (Figs. 1(a), (b), (e), and 2)

Compared to the other groups, the energy output of the calculus $\mathrm{W}(+)$ group declined the most rapidly to $33.4 \mathrm{~mJ}(83.5 \%)$ on average after $10 \mathrm{~min}$ (Fig. 2). After $20 \mathrm{~min}$, the energy level was maintained around 32.7-34.1 mJ (81.8-85.0\%) before declining to $31.6 \mathrm{~mJ}$ (79.0\%) after 60-min irradiation (Figs. 1(c), (e), and 2). However, one tip in this group showed a sudden, rapid reduction to $26.7 \mathrm{~mJ}(66.8 \%)$ at $20 \mathrm{~min}$, declining to 18.2 $\mathrm{mJ}(45.6 \%)$ after $60 \mathrm{~min}$.

In the bone $\mathrm{W}(+)$ group, most of the tips exhibited a gradual reduction and finally declined to $69.6 \mathrm{~mJ}(87.0 \%)$ on average after $60 \mathrm{~min}$ from $80 \mathrm{~mJ}$ initially (Figs. 1(d), (e), and 2).

The energy output ratio declined the most in the calculus $\mathrm{W}(+)$ group $(79.0 \%)$, followed by the bone $\mathrm{W}(+)$ group (87.0\%), the soft tissue $\mathrm{W}(+)$ group $(91.4 \%)$, and the soft tissue W(-) group (94.3\%) (Fig. 2). In the calculus group, the energy output ratio declined significantly compared to the other three groups at $1,3,5,10$, and 20 $\min (p<0.05)$. Significant reductions in the calculus $\mathrm{W}(+)$ group were also observed at 30,40, and 50 min compared to the soft tissue $\mathrm{W}(-)$ group $(p<0.05)$ and at $40 \mathrm{~min}$ compared to the bone $\mathrm{W}(+)$ group $(p<0.05)$. However, after $60 \mathrm{~min}$, no statistically significant differences were observed among the groups (Fig. 2).

\section{Morphological analysis of the contact surface}

Under stereomicroscopy, a flat, smooth, and mirrorlike contact surface was observed on the unused quartz contact tip. The contact surface is composed of three areas: 1) the optical fiber, 2) the cladding, and 3) the surrounding jacket layer that protects the fiber (Fig. 3(a)). The contact surface of the quartz tips in the soft tissue $\mathrm{W}(-)$ and $\mathrm{W}(+)$ groups maintained a smooth appearance with minimal alteration after 60 min (Figs. 3(b) and (c)), but the jacket layer revealed a charred feature only in the soft tissue W(-) group (Fig. 3(b)).

In the calculus $\mathrm{W}(+)$ group and bone $\mathrm{W}(+)$ group, the contact surface showed obvious damage and deterioration (Figs. 3(d) and (e)). The jacket layer surrounding the fiber was severely destroyed. Tipping and fracturing were observed at the exposed periphery of the fiber, and the contact surface showed irregular features (Fig. 3(d) and (e)).

Under SEM observation, among all groups, the least amount of debris was attached on the surface in the soft tissue W(-) group (Fig. 3(1)); moreover, the surface was relatively smooth except for the partial presence of small holes and defects, which were the size of a few microns (Figs. 3(q) and (v)). In the soft tissue W(+) group, microdebris less than $1 \mu \mathrm{m}$ in size was sparsely attached on the surface (Figs. 3(r) and (w)), and at higher magnification (Figs. 3(r) and (w)), it was found that under the attached micro-debris, the original surface was uniformly coated with a very thin layer of material having numerous micro-holes with maximal diameter of $1 \mu \mathrm{m}$ (Fig. 3(w)).

In the calculus $\mathrm{W}(+)$ group, the original surface became micro-irregular (Fig. 3(n)), and numerous 

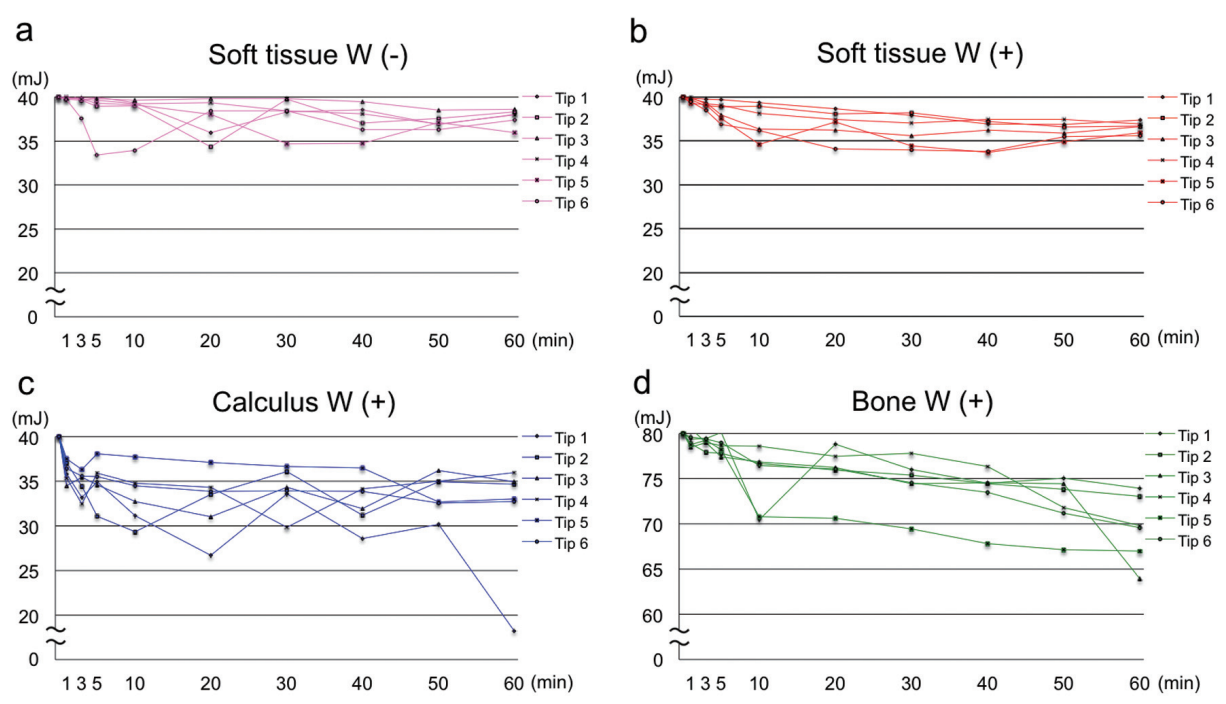

e

\begin{tabular}{|c|c|c|c|c|c|c|c|c|c|c|c|}
\hline \multicolumn{12}{|c|}{ Energy output (mJ) } \\
\hline Time $(m$ & & 0 & 1 & 3 & 5 & 10 & 20 & 30 & 40 & 50 & 60 \\
\hline Soft tissue & $W(-)$ & 40 & $39.9 \pm 0.4$ & $39.4 \pm 0.9$ & $38.6 \pm 2.5$ & $38.4 \pm 2.2$ & $37.7 \pm 2.1$ & $38.3 \pm 1.9$ & $37.4 \pm 1.7$ & $37.2 \pm 0.8$ & $37.7 \pm 0.9$ \\
\hline Soft tissue & $W(+)$ & 40 & $39.7 \pm 0.3$ & $39.2 \pm 0.4$ & $38.4 \pm 1.1$ & $37.3 \pm 1.8$ & $36.9 \pm 1.6$ & $36.2 \pm 1.8$ & $35.9 \pm 1.7$ & $36.2 \pm 0.9$ & $36.5 \pm 0.7$ \\
\hline Calculus & $W(+)$ & 40 & $36.1 \pm 1.1$ & $34.6 \pm 1.5$ & $35.0 \pm 2.3$ & $33.4 \pm 3.0$ & $32.8 \pm 3.5$ & $34.1 \pm 2.4$ & $32.7 \pm 2.7$ & $33.6 \pm 2.2$ & $31.6 \pm 6.7$ \\
\hline Bone & W (+) & 80 & $79.3 \pm 0.8$ & $79.0 \pm 0.6$ & $78.6 \pm 0.9$ & $75.0 \pm 3.5$ & $75.9 \pm 2.8$ & $74.6 \pm 2.8$ & $73.5 \pm 2.9$ & $72.3 \pm 2.9$ & $69.6 \pm 3.7$ \\
\hline
\end{tabular}

Fig. 1 Changes in the energy output of quartz tips over time after ErL contact irradiation on different target tissues.

For irradiation on soft tissue without and with water spray [soft tissue W(-) and W(+) groups], most of the tips exhibited a gradual, continuous energy output reduction, reaching around 35-38 mJ/pulse $(37.7$ and $36.5 \mathrm{~mJ} / \mathrm{pulse}$ on average, respectively) from $40 \mathrm{~mJ} /$ pulse initially (a, b, and e). For irradiation on subgingival calculus with water spray [calculus $\mathrm{W}(+)$ group], the energy output of the tips showed a relatively rapid reduction, declining to 33-36 $\mathrm{mJ} /$ pulse $(31.6 \mathrm{~mJ} /$ pulse on average), with the exception of one tip, which showed a sudden and marked reduction to $18.2 \mathrm{~mJ} /$ pulse at $60 \mathrm{~min}$ (c and e). For irradiation on bone tissue with water spray [bone W(+) group], most of the tips exhibited a gradual reduction, declining to $63-73 \mathrm{~mJ} /$ pulse $(69.6 \mathrm{~mJ} /$ pulse on average) after 60-min irradiation from $80 \mathrm{~mJ} /$ pulse initially ( $\mathrm{d}$ and e). Each data represents the mean $\pm \mathrm{SE}(n=6)(\mathrm{e})$. W: water spray during irradiation.

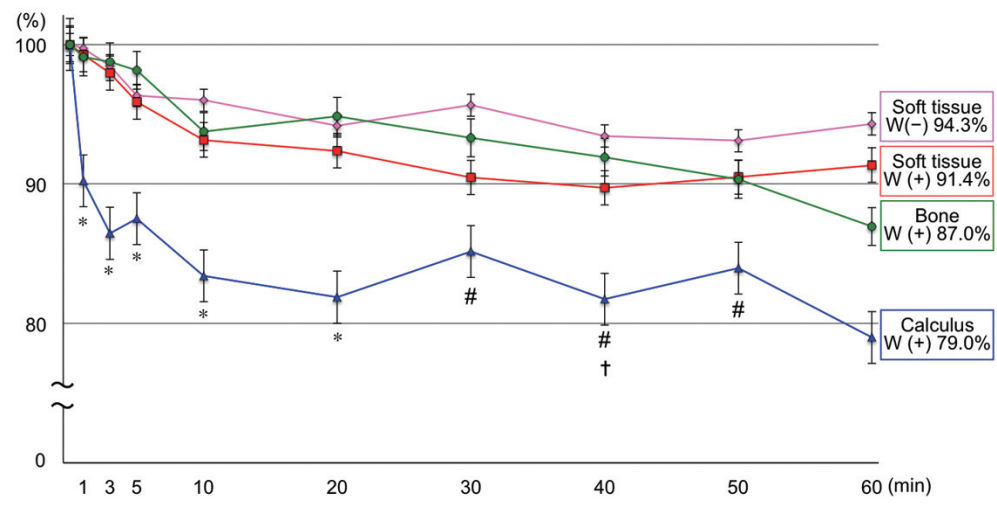

Fig. 2 Changes in the average energy output ratio of quartz tips over time after ErL contact irradiation on different target tissues.

In the calculus $\mathrm{W}(+)$ group, the energy output ratio declined the most rapidly at 10 min after beginning irradiation, whereas the other groups showed similar gradual reductions, regardless of the original energy output level. The final energy output ratio on average declined the most in the calculus $\mathrm{W}(+)$ group $(79.0 \%)$, followed by the bone $\mathrm{W}(+)$ group (87.0\%), soft tissue W(+) group (91.4\%), and soft tissue W(-) group (94.3\%). The soft tissue W(+) group showed slightly higher energy output reduction than the soft tissue W(-) group. Each data represents the mean $\pm \mathrm{SE}(n=6)$. ${ }^{*} p<0.05$, calculus $\mathrm{W}(+)$ group vs. other three groups; $\# p<0.05$, calculus $\mathrm{W}(+)$ group vs. soft tissue $\mathrm{W}(-)$ group; $† p<0.05$, calculus $\mathrm{W}(+)$ group vs. bone $\mathrm{W}(+)$ group; Tukey-Kramer post-hoc test. W: water spray during irradiation. 


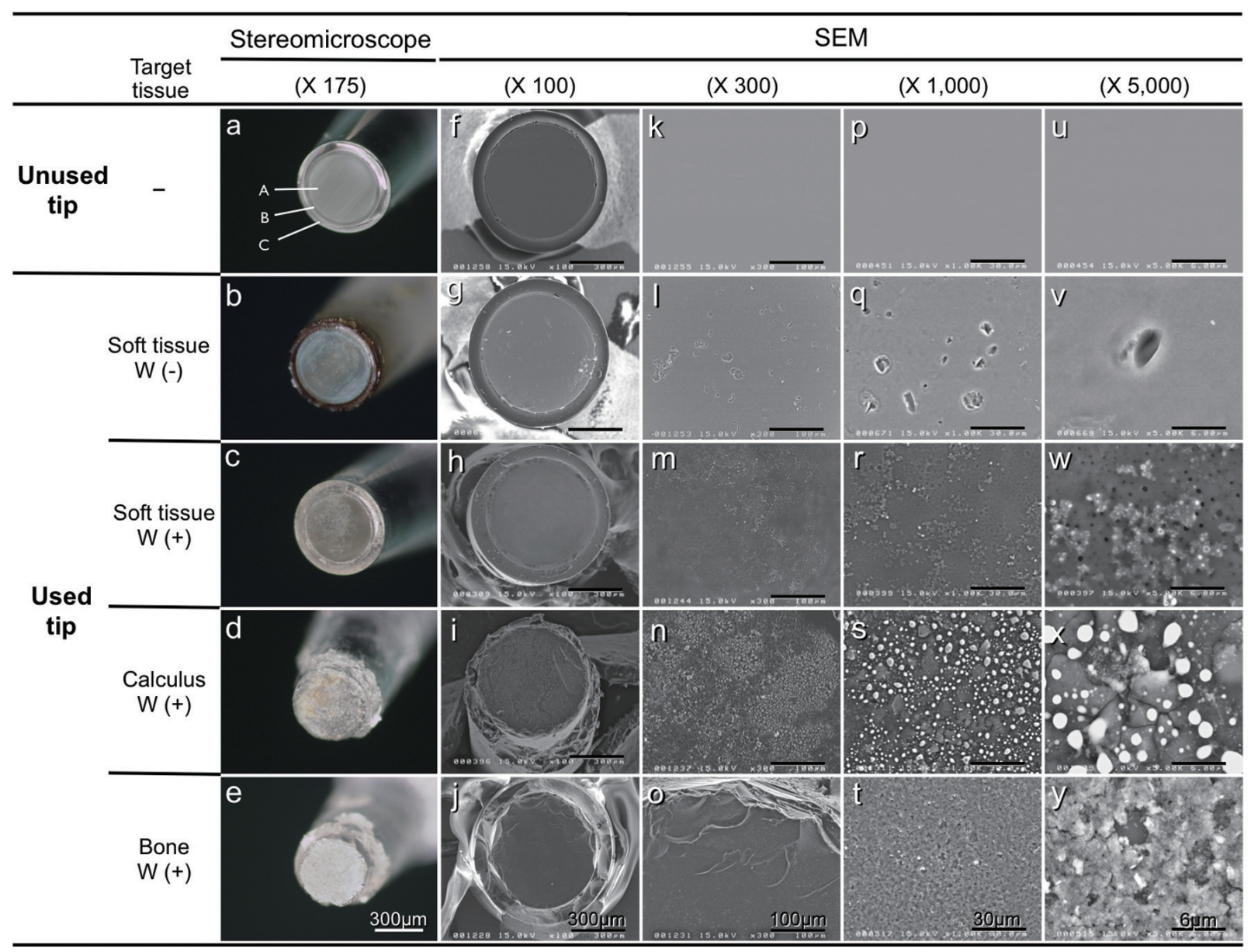

Fig. 3 Stereomicroscopy and scanning electron microscopy of the quartz tip contact surface before and after 60-min ErL irradiation.

Under stereomicroscopy, a flat, smooth, and mirror-like contact surface was observed on the unused quartz contact tip (a). The contact surface is composed of three areas: the optical fiber (a-A), the cladding (a-B), and the surrounding jacket layer (a-C) around the fiber. After 60-min irradiation, the contact surface of quartz tips in the soft tissue $\mathrm{W}(-)$ and $\mathrm{W}(+)$ groups maintained a smooth appearance with minimal alteration (b and c), but the surrounding jacket layer revealed a charred feature in the soft tissue W(-) group (b). In the calculus W(+) group and the bone $\mathrm{W}(+)$ group, the contact surface showed obvious damage and irregularity ( $\mathrm{d}$ and e). The surrounding jacket layer was severely destroyed, while tipping and fracturing were observed at the exposed fiber periphery $(\mathrm{d}$ and e). Under SEM observation, in the soft tissue W(-) group, the least amount of debris was attached on the surface compared to the hard tissue groups, and the surface was relatively smooth (g) except for the partial presence of small holes and defects $(1, q$, and v). In the soft tissue W(+) group, the contact surface was almost smooth (h), and micro-debris was sparsely attached on the surface ( $m$ and $r$ ). At higher magnification, under the attached micro-debris, the original surface was uniformly coated with a very thin layer of substance having numerous micro-holes (w). In the calculus $\mathrm{W}(+)$ group, the original surface became micro-irregular by slight surface ablation and attachments (i and n), and numerous characteristically resolidified, round micro-particles were predominantly attached on the surface. Microcracks of the surface with fused substances were also noted ( $\mathrm{s}$ and $\mathrm{x}$ ). In the bone W(+) group, the surface became partially rugged ( $\mathrm{j}$ and $\mathrm{o}$ ) due to the major tipping and fracturing, which occurred from the peripheral area of the fiber, and the exposure of the original surface was very limited since the surface was almost covered by fibrous debris (t and $\mathrm{y})$.

characteristically resolidified, round micro-particles with approximate diameters of $1-5 \mu \mathrm{m}$ were predominantly attached on the surface (Figs. 3(s) and (x)). Moreover, the surface of one tip, which showed the highest energy output reduction, was almost covered by resolidified, round micro-particles that were larger in size and number than those on the surface of the other tips.

In the bone $\mathrm{W}(+)$ group, the surface became partially rugged due to major tipping and fracturing, which occurred in the peripheral areas (Figs. 3(j) and (o)). 


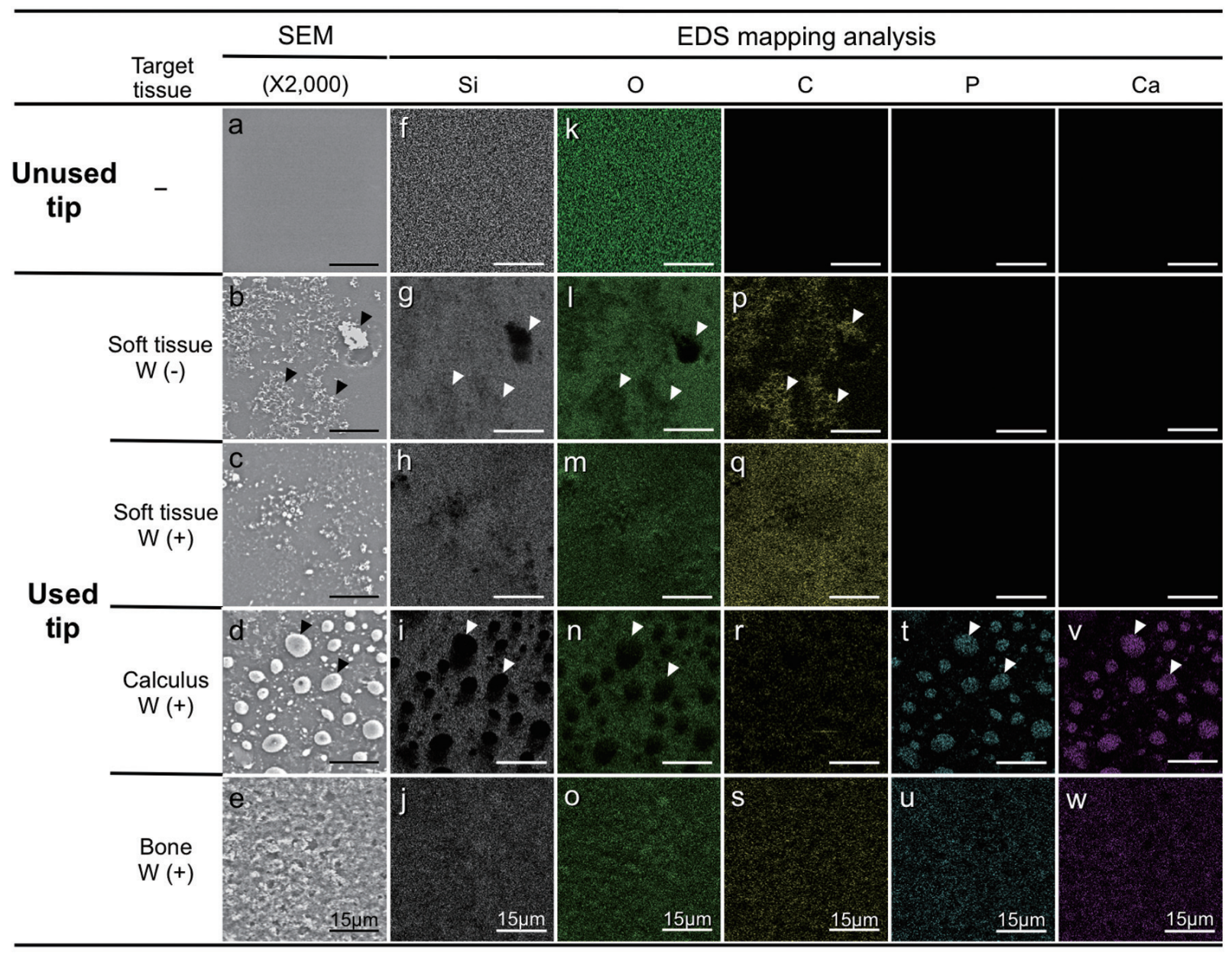

Fig. 4 The SEM-EDS mapping analysis of the quartz tip contact surface after 60-min ErL irradiation.

A representative feature of the quartz tip contact surface in each group is shown by SEM (a-e). The unused quartz tip showed a smooth contact surface (a), and Si and $\mathrm{O}$ were uniformly detected on the entire surface (f and $\mathrm{k}$ ). In the soft tissue $\mathrm{W}(-)$ group, coinciding with the presence of attachments observed in the SEM (b, arrows), both Si and $\mathrm{O}$ were not observed (g and $\mathrm{l}$ ), while $\mathrm{C}$ was strongly detected at the attachment sites (p). In the soft tissue W(+) group, $\mathrm{C}$ was detected more strongly and uniformly (q) regardless of the absence of attached debris in the SEM (c). In the calculus $\mathrm{W}(+)$ group, coinciding with the presence of round shape attachments in the SEM (d, arrows), both Si and $\mathrm{O}$ were clearly lacking (i and $\mathrm{n}$ ), while both $\mathrm{P}$ and $\mathrm{Ca}$ were strongly detected ( $\mathrm{t}$ and $\mathrm{v}$ ). Furthermore, weak and sparse distribution of $\mathrm{C}$ was observed $(\mathrm{r})$. In the bone $\mathrm{W}(+)$ group, the foreign $\mathrm{C}, \mathrm{P}$, and Ca elements were uniformly detected (s, u and w) according to the uniform attachment of the fibrous debris (e). Si: silicon; O: oxygen; C: carbon; P: phosphorus; Ca: calcium (original magnification: 2000×).

Furthermore, the surface was almost covered by fibrous debris with diameters of 4-5 $\mu \mathrm{m}$, severely limiting the original surface exposure (Figs. 3(t) and (y)).

Thus, the features and shapes of the substances attached to the contact surface were markedly different among the experimental groups.

\section{Compositional analysis of the contact surface}

The SEM-EDS mapping analysis demonstrated that $\mathrm{Si}$ and $\mathrm{O}$ were uniformly distributed over the entire contact surface (Figs. 4(f) and (k)) as original constituents of the quartz tip. In the soft tissue $\mathrm{W}(-)$ group, $\mathrm{C}$ was detected strongly at the sites (Fig. 4(p)) where fibrous debris was observed in the SEM images (Fig. 4(b)). In the soft tissue $\mathrm{W}(+)$ group, C was detected more strongly and uniformly (Fig. 4(q)) even at sites observed without debris in the SEM images (Fig. 4(c)).

In the calculus $\mathrm{W}(+)$ group, coinciding with the presence of round attached shapes in the SEM images (Fig. 4(d)), both Si and O were clearly lacking (Figs. 4(i) and (n)), and both $\mathrm{P}$ and Ca were strongly detected (Figs. $4(\mathrm{t})$ and $(\mathrm{v}))$. In the bone $\mathrm{W}(+)$ group, the foreign $\mathrm{C}, \mathrm{P}$, and Ca elements were uniformly detected (Figs. 4(s), (u), and (w)) according to the uniform attachment of fibrous debris (Fig. 4(e)).

The EDS area analysis indicated that both $\mathrm{Si}$ and 


\begin{tabular}{|c|c|c|c|c|c|c|c|c|c|}
\hline & \multirow[b]{3}{*}{ Target tissue } & \multicolumn{8}{|c|}{ Number concentration of element (\%) } \\
\hline & & \multicolumn{3}{|c|}{ Original element } & \multicolumn{5}{|c|}{ Foreign element } \\
\hline & & $\mathrm{Si}$ & 0 & $(\mathrm{Si}+\mathrm{O})$ & C & $\mathrm{P}$ & $\mathrm{Ca}$ & $\mathrm{Na}$ & $\mathrm{Mg}$ \\
\hline Unused tip & - & $38.3 \pm 0.6$ & $61.7 \pm 0.6$ & $(100.0 \pm 0.0)$ & 0 & 0 & 0 & 0 & 0 \\
\hline \multirow{4}{*}{ Used tip } & Soft tissue W (-) & $28.4 \pm 5.5$ & $53.8 \pm 6.0$ & $(82.2 \pm 11.0)$ & $17.8 \pm 11.0$ & 0 & 0 & 0 & 0 \\
\hline & Soft tissue W $(+)$ & $17.1 \pm 1.8$ & $29.7 \pm 3.0$ & $(46.8 \pm 4.6)$ & $53.2 \pm 4.6$ & 0 & 0 & 0 & 0 \\
\hline & Calculus W(+) & $17.4 \pm 5.4$ & $38.1 \pm 13.2$ & $(55.5 \pm 18.2)$ & $34.9 \pm 20.4$ & $3.9 \pm 1.5$ & $4.9 \pm 1.8$ & $0.5 \pm 0.5$ & $0.3 \pm 0.3$ \\
\hline & $\mathrm{W}(+)$ & $21.5 \pm 1.4$ & $41.3 \pm 3.8$ & $(62.8 \pm 4.6)$ & $32.5 \pm 3.5$ & $2.1 \pm 0.7$ & $2.6 \pm 1.0$ & 0 & 0 \\
\hline
\end{tabular}

b

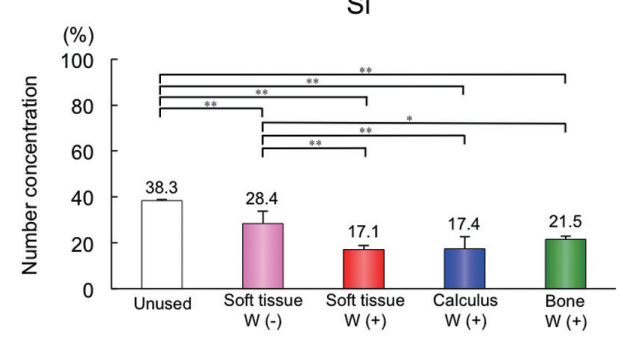

d

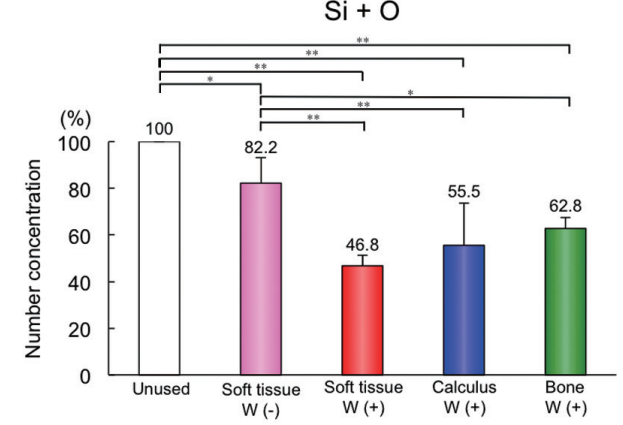

C

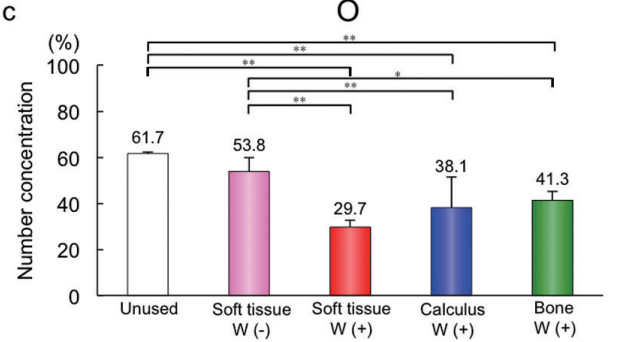

e

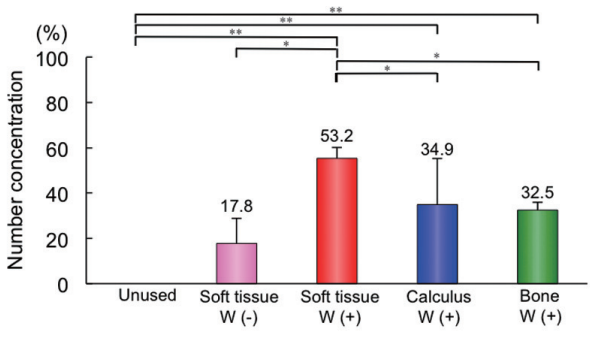

Fig. 5 The SEM-EDS area analysis of the contact surface of quartz tips after 60-min ErL irradiation.

On the unused quartz tip contact surface, only Si and O were detected, and the amount of Si+O was 100\% (a). Both $\mathrm{Si}$ and $\mathrm{O}$ significantly decreased in all experimental groups after 60-min irradiation, except for $\mathrm{O}$ in the soft tissue W(-) group ( $\mathrm{a}, \mathrm{b}$ and $\mathrm{c}$ ). The amount of $\mathrm{Si}+\mathrm{O}$ also significantly decreased after 60-min irradiation in all experimental groups, and it was the lowest in the soft tissue $\mathrm{W}(+)$ group $(46.8 \%)$, followed by calculus $\mathrm{W}(+)(55.5 \%)$, bone $\mathrm{W}(+)(62.8 \%)$, and soft tissue $\mathrm{W}(-)(82.2 \%)$ group (a). The amount of $\mathrm{Si}+\mathrm{O}$ in the soft tissue $\mathrm{W}(+)$ group was significantly lower than that of the soft tissue W(-) group (a and d). Carbon, the main contaminant, was observed in all experimental groups, and the amount of $\mathrm{C}$ was the highest in the soft tissue $\mathrm{W}(+)$ group with a significant difference from the other groups $(p<0.05$ ) (a and e). $\mathrm{P}$ and $\mathrm{Ca}$ were slightly detected in the bone and calculus groups, while $\mathrm{Na}$ and $\mathrm{Mg}$ were very slightly detected in the calculus $\mathrm{W}(+)$ group (a). Si: silicon; O: oxygen; C: carbon; P: phosphorus; Ca: calcium; Na: sodium; Mg: magnesium; W: water spray during irradiation. Each data represents the mean $\pm \mathrm{SD}(n=6) .{ }^{*} p<0.05$, $* * p<0.01$ Tukey-Kramer post-hoc test.

O significantly decreased after 60-min irradiation in all the experimental groups, with the exception of $\mathrm{O}$ in the soft tissue $\mathrm{W}(-)$ group (Figs. 5(a), (b), and (c)). The total amount of $\mathrm{Si}+\mathrm{O}$ (i.e., the exposure of the original contact surface) significantly decreased after 60-min irradiation in all the groups, and it was the lowest in the soft tissue $\mathrm{W}(+)$ group (46.8\%), followed by the calculus $\mathrm{W}(+)(55.5 \%)$, bone $\mathrm{W}(+)(62.8 \%)$, and soft tissue $\mathrm{W}(-)$ (82.2\%) groups. The amount of $\mathrm{Si}+\mathrm{O}$ in the soft tissue $\mathrm{W}(+)$ group $(46.8 \%)$ was significantly lower than that of the soft tissue W(-) group (82.2\%) (Fig. 5(d)).

Carbon was the primary contaminant and was observed in all experimental groups, and the amount of $\mathrm{C}$ was significantly higher in the soft tissue $\mathrm{W}(+)$ group
(53.2\%) (Fig. 5(e)) compared to the other groups $(p<0.05)$ (Fig. 5e). In particular, the amount of $\mathrm{C}$ was three times higher in the soft tissue $\mathrm{W}(+)$ group than in the $\mathrm{W}(-)$ group. In addition to $\mathrm{C}, \mathrm{P}$ and $\mathrm{Ca}$ were slightly detected in the bone and calculus groups. Moreover, $\mathrm{Na}$ and $\mathrm{Mg}$ were very slightly detected in the calculus group (Fig. $5(a))$.

Temperature changes of all irradiation groups over time Figure 6 shows the temperature changes of the tip end in all irradiation groups over time.

With water spray, a very slight temperature elevation was observed, and the increased temperature from $26.1^{\circ} \mathrm{C}$ at the beginning of irradiation remained 


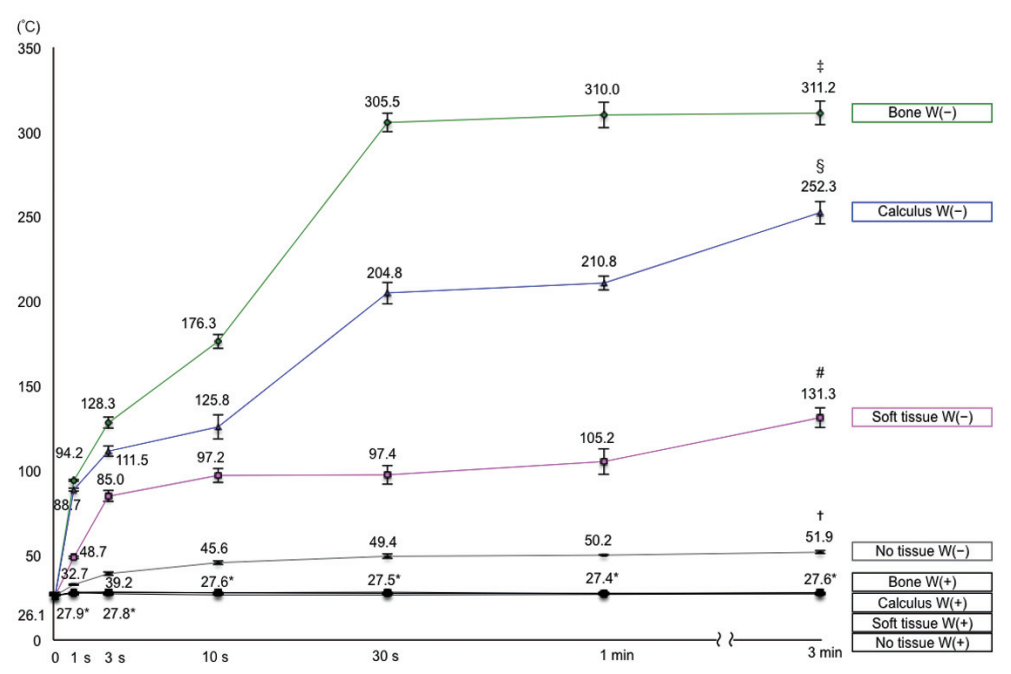

Fig. 6 Temperature changes of the contact tips over time after ErL contact irradiation on different target tissues.

With water spray, a very slight temperature elevation was observed, and the increased temperature from $26.1^{\circ} \mathrm{C}$ at the beginning of the irradiation remained around $28^{\circ} \mathrm{C}$ until $3 \mathrm{~min}$ in all groups. Without water spray, in the no tissue $\mathrm{W}(-)$ group, the temperature gradually increased to $51.9^{\circ} \mathrm{C}$ at $3 \mathrm{~min}$. In the soft tissue, calculus, and bone $\mathrm{W}(-)$ groups, the temperature rapidly and significantly increased to $48.7,88.7$, and $94.2^{\circ} \mathrm{C}$ at $1 \mathrm{~s}, 85.0,111.5$, and $128.3^{\circ} \mathrm{C}$ at $3 \mathrm{~s}, 97.2,125.8$, and $176.3^{\circ} \mathrm{C}$ at $10 \mathrm{~s}, 97.4,204.8,305.5^{\circ} \mathrm{C}$ at $30 \mathrm{~s}, 105.2,210.8$, and $310.0^{\circ} \mathrm{C}$ at $1 \mathrm{~min}$, and $131.3,252.3$, and $311.2^{\circ} \mathrm{C}$ at $3 \mathrm{~min}$, respectively. ${ }^{*}$ : average temperature of the four water (+) groups. Each data point represents the mean $\pm \mathrm{SE}(n=4)$. The total amount of temperature elevation in the W(-) groups was significantly different among the four different target tissues $(p<0.001)$ : bone tissue W $(-)$ group was the highest, followed by that of the calculus $\mathrm{W}(-)$, soft tissue $\mathrm{W}(-)$, and no tissue $\mathrm{W}(-)$ group. $\dagger: p<0.001$, compared to no tissue $\mathrm{W}(+)$, soft tissue $\mathrm{W}(-)$, calculus $\mathrm{W}(-)$, and bone $\mathrm{W}(-)$ group; \#: $p<0.001$, compared to soft tissue $\mathrm{W}(+)$, no tissue $\mathrm{W}(-)$, calculus $\mathrm{W}(-)$, and bone $\mathrm{W}(-)$ group; $\S: p<0.001$, compared to calculus $\mathrm{W}(+)$, no tissue $\mathrm{W}(-)$, soft tissue $\mathrm{W}(-)$ and bone $\mathrm{W}(-)$ group; $\ddagger: p<0.001$, compared to bone $\mathrm{W}(+)$, no tissue $\mathrm{W}(-)$, soft tissue $\mathrm{W}(-)$, and calculus $\mathrm{W}(-)$ group. No significant difference was observed among the each four $\mathrm{W}(+)$ groups. Two-factor ANOVA followed by $t$-test with Bonferroni correction.

around $28^{\circ} \mathrm{C}$ until $3 \mathrm{~min}$ in all groups.

Without water spray, in the no tissue $\mathrm{W}(-)$ group, the temperature gradually increased to $51.9^{\circ} \mathrm{C}$ at 3 min. In the soft tissue, calculus, and bone $\mathrm{W}(-)$ groups, the temperature rapidly and significantly increased to $48.7,88.7$, and $94.2^{\circ} \mathrm{C}$ at $1 \mathrm{~s}, 85.0,111.5$, and $128.3^{\circ} \mathrm{C}$ at $3 \mathrm{~s}, 97.2,125.8$, and $176.3^{\circ} \mathrm{C}$ at $10 \mathrm{~s}, 97.4,204.8$, $305.5^{\circ} \mathrm{C}$ at $30 \mathrm{~s}, 105.2,210.8$, and $310.0^{\circ} \mathrm{C}$ at $1 \mathrm{~min}$, and $131.3,252.3$, and $311.2^{\circ} \mathrm{C}$ at $3 \mathrm{~min}$, respectively.

The factor of 'target material' and 'water spray' as well as the interaction between the two factors was statistically significant $(p=0.003, p<0.0001$, and $p<0.0001$, respectively). The temperature elevation in the $\mathrm{W}(-)$ groups was significantly different among the four different target tissues $(p<0.001)$ : bone tissue $\mathrm{W}(-)$ group was the highest, followed by the calculus $\mathrm{W}(-)$ group, soft tissue $\mathrm{W}(-)$ group, and no tissue $\mathrm{W}(-)$ group. In the same target tissue groups, the temperature elevation of $\mathrm{W}(-)$ group was significantly higher than that of $\mathrm{W}(+)$ group, respectively. No significant difference was observed among the four water $(+)$ groups (Fig. 6).

\section{DISCUSSION}

Because the energy output influences the safety and effectiveness of laser treatment during clinical application, operators need to precisely understand the actual energy output level. However, information concerning the alteration of contact tips and changes in energy output after periodontal applications is insufficient ${ }^{37-41}$. Therefore, in the present study, changes in the energy output and surface topography of the quartz tips following ErL contact irradiation on periodontal soft and hard tissues were investigated. Generally, ErL is used with water cooling to facilitate ablation and to prevent thermal damage during ablation of both soft and hard tissues such as gingiva, teeth, calculus, and alveolar bone ${ }^{42-45)}$, but occasionally, ErL is used without water cooling on soft tissues to enhance hemostasis by thermal effects. Therefore, in the present study, the irradiation was conducted with water spray in hard tissue ablation, and irradiation was employed both with and without water spray in soft tissue ablation.

After contact usage, the results of the present study showed a gradual reduction of energy output in all experimental groups over time. The rate of energy reduction after 60 -min irradiation was minimal for soft 
tissue ablation, and the soft tissue $\mathrm{W}(-)$ group maintained the highest energy output ratio (94.3\%), followed by the soft tissue $\mathrm{W}(+)(91.4 \%)$ and bone $\mathrm{W}(+)(87.0 \%)$ groups. The lowest energy output ratio was observed in the calculus $\mathrm{W}(+)$ group (79.0\%); however, these values were much higher than the remarkable reduction shown for enamel ablation (45.3\%), which was previously reported by Eguro et al. ${ }^{40)}$.

Unlike the hard tissue groups such as calculus and bone ablation, the contact surface of quartz tips in the soft tissue groups maintained a smooth appearance without incurring severe surface degradation even after 60-min irradiation. Consequently, higher energy output ratio levels were maintained in the soft tissue groups compared to those in the hard tissue groups. The use of water spray influenced the alteration of the contact surface in an unexpected manner. The EDS analyses revealed that the tip surface was contaminated by $\mathrm{C}$ in both soft tissue $\mathrm{W}(-)$ and $\mathrm{W}(+)$ groups; however, $\mathrm{C}$ was more significantly and uniformly detected in the $\mathrm{W}(+)$ group (53.2\%) than in the $\mathrm{W}(-)$ group $(17.8 \%)$, regardless of the presence or absence of debris. The higher magnification SEM views presented an interesting finding: the entire surface of tips in the $\mathrm{W}(+)$ group was coated by a very thin layer of amorphous material having numerous tiny holes, which was possibly produced by evaporation of the target soft tissue. Consequently, the exposure of the original contact surface (the total amount of the original $\mathrm{Si}+\mathrm{O}$ elements) was significantly lower in the $\mathrm{W}(+)$ group (46.8\%) than that of the W(-) group $(82.2 \%)$. These results also revealed more organic contamination of the contact surface in the soft tissue $\mathrm{W}(+)$ group, which may explain the lower energy output level in the soft tissue $\mathrm{W}(+)$ group (91.4\%) compared to that of the soft tissue $\mathrm{W}(-)$ group $(94.3 \%)$. However, the difference in the energy output ratio between the $\mathrm{W}(+)$ and $\mathrm{W}(-)$ groups was not as large as the difference in the level of Si+O exposure between the $\mathrm{W}(+)$ and $\mathrm{W}(-)$ groups. Given that the morphological alteration of the contact surface was similar between the two groups, these findings mean that the thin layer of $\mathrm{C}$ contamination did not strongly block, absorb, or diffuse the laser beam.

Contrary to our expectations before the experiment, the surface alteration was similar between the soft tissue $\mathrm{W}(+)$ and $\mathrm{W}(-)$ groups. The water cooling did not substantially prevent the reduction of energy output and tended to promote it due to the enhanced $\mathrm{C}$ contamination on the contact surface. The mechanism enabling organic material, including $\mathrm{C}$ derived from the target soft tissue, attachment to the contact surface during irradiation with water spray is unknown. One possible hypothesis is that immediately after being melted and vaporized during irradiation, the evaporated material was rapidly cooled and solidified by the water spray, resulting in the thin film attachment on the tip surface.

The morphology of the contact surface in the calculus $\mathrm{W}(+)$ and bone $\mathrm{W}(+)$ groups was more irregular compared to that of the soft tissue groups: roughened, tipped, or fractured surfaces were observed accompanied with the complete destruction of jacket layer, resulting in higher energy reductions. As for the mechanism of surface deterioration, the attrition and abrasion caused by mechanical impact and thermal stress during contact irradiation are speculated as potential causes ${ }^{38)}$. The mechanical impact would be caused by extensive pressure and shock waves including micro-explosive ablation that produces high-speed hard tissue fragments. Thus, the distinct tip-wear observed in hard tissue groups would be primarily due to high mechanical stress during ablation. However, compared to the severe concavity observed in the case of enamel ablation ${ }^{40)}$, the degree of surface abrasion in the calculus and bone groups was much smaller in the present study. These differences could be attributed to the difference in the hardness of the target tissues as well as the level of energy output employed.

Regarding the attached foreign elements, the amount of $\mathrm{C}$ was similar between the calculus (34.9\%) and bone (32.5\%) groups, whereas the total amount of inorganic elements $(\mathrm{P}, \mathrm{Ca}, \mathrm{Na}$, and $\mathrm{Mg})$ was higher in the calculus $\mathrm{W}(+)$ group $(9.6 \%)$ than in the bone $\mathrm{W}(+)$ group $(4.7 \%)$. Furthermore, the total amount of $\mathrm{Si}+\mathrm{O}$ in the calculus $\mathrm{W}(+)$ group $(55.5 \%)$ was lower than that of the bone $\mathrm{W}(+)$ group $(62.8 \%)$. These results indicate that the higher energy reduction in the calculus $\mathrm{W}(+)$ group $(79.0 \%)$ compared to the bone $\mathrm{W}(+)$ group $(87.0 \%)$ may be partly a result of the higher level of inorganic attachments on the tip surface in addition to contact surface alteration. This result leads to the speculation that, unlike organic attachments, inorganic attachments possess higher potential for scattering, defocusing, or blocking the laser beam during irradiation. In fact, in the calculus $\mathrm{W}(+)$ group, the SEM images of one tip, which showed a marked energy output reduction, demonstrated that the size and amount of $\mathrm{Ca}$ and $\mathrm{P}$ attachments on the contact surface was much larger than those of other tips, although the contact surface irregularity was similar to that of other tips in the same group. These findings further suggest that the size and amount of inorganic contamination may highly influence energy output reduction.

During laser tissue ablation, thermogenesis is inevitable and will affect the surface of contact tips. To evaluate the temperature elevation of the contact tip during irradiation, thermography was employed. However, measurement of the temperature changes during irradiation was difficult. In particular, precisely determining the real temperature of the contact surface during irradiation was basically impossible, and even when the temperature of the lateral surface was employed, the sprayed water covering the contact tip surface might have masked the real temperature of tip during irradiation with water spray. In fact, in all $\mathrm{W}(+)$ groups, no significant temperature elevation was detected. Therefore, in addition to the soft tissue $\mathrm{W}(+)$ group, the temperature increase during irradiation without water spray was determined in other tissue groups to clarify the difference in heat generation during ablation depending on the different tissues, thereby allowing speculation of the degree of potential thermal 
influence on the contact surface during irradiation with water spray.

The results of the temperature changes in all W(-) groups provided useful information. The temperature of the no tissue W(-) group gradually increased over time and reached around $51.9^{\circ} \mathrm{C}$ at $3 \mathrm{~min}$, indicating a moderate temperature increase of the tip with only laser irradiation. In the soft tissue, calculus, and bone W(-) groups, severe temperature elevations were observed and the temperature reached $131.3,252.3$, and $311.2^{\circ} \mathrm{C}$ at $3 \mathrm{~min}$, respectively.

In the soft tissue $\mathrm{W}(-)$ group, this level of temperature elevation actually caused carbonization of the jacket layer of the contact tip; however, severe thermal damage of the contact surface was not detected. Because the melting point of quartz is $1,650^{\circ} \mathrm{C}$, a temperature of approximately $130^{\circ} \mathrm{C}$ would not affect the quartz glass. In the soft tissue W(+) group, the temperature of the tip remained around $28^{\circ} \mathrm{C}$. Morphological observation showed no charred features of the jacket layer and no carbonized substances on the contact surface, except for the attachment of evaporated and resolidified organic material. Thus, the temperature elevation of the contact surface should have been minimal as the lateral surface of the tip indicated only a very slight temperature increase.

In the hard tissue, calculus, and bone $\mathrm{W}(-)$ groups, much higher temperature elevations of the contact tip were detected than in the soft tissue W(-) group, possibly due to larger thermogenesis during ablation in tissue with a much lower content of water. After only 1 $\mathrm{s}$, the temperatures reached $85-100^{\circ} \mathrm{C}$ in these groups. Thus, compared to soft tissue ablation, a momentary temperature increase at the contact surface is speculated to be larger in hard tissue ablation during contact irradiation even with water spray, and therefore, the increased temperature may have affected and influenced the alteration of the contact surface.

Generally, the destruction of the contact surface could be caused by physical stresses such as severe impact from extensive pressure and shock waves as well as by the thermal stress of the momentary temperature increase of the contact surface, which is inevitable during contact irradiation even though water spray is used ${ }^{40)}$. However, considering the present results showing only very slight temperature increases of the lateral surface of the tips, water spray may have effectively minimized the temperature elevation of the tips, thereby minimizing the thermal damage of the contact surface. In fact, higher temperature elevation was observed in the bone W(-) group than in the calculus W(-) group, which may be primarily due to the higher energy output applied in the bone group; however, the rate of energy output reduction was lower in the bone $\mathrm{W}(+)$ group than in the calculus $\mathrm{W}(+)$ group, suggesting that factors other than thermal influence during irradiation with water spray (possibly contamination of contact surface) affected the contact surface more strongly, thereby reducing the energy output. Because a momentary temperature increase of the contact surface was not directly determined in the present study, further analysis is required for precisely understanding the thermal change of the contact surface during irradiation with water spray. These results also suggest the importance of water spray, especially during irradiation on hard tissues, to minimize the thermal accumulation in tips during ablation and thereby increase the longevity of the contact surface.

In the present study, it was clarified that the used tips are contaminated with various foreign attachments, which could not be removed by water rinsing alone. Therefore, further studies are required to establish a standard protocol for cleaning used tips such as manual wiping, ultrasonication, or soaking in a particular solution. Furthermore, additional studies are needed to determine an effective method for regaining the energy output of used tips. Previously, Yamazaki et al. ${ }^{41)}$ have demonstrated that polishing used quartz tips with silicon carbide paper was effective for regaining energy output by smoothing irregularities as well as removing attached substances on the contact surface.

In the hard tissue groups, the destruction of the fiber jacket layer was clearly observed followed by tipping of the exposed fiber. With respect to the longevity of contact tips, the role of jacket layer is considered to be important for not only protecting the core fiber but also sustaining the energy output. Therefore, equipment with robust jacket layers would be preferable to prevent destruction of the contact surface as well as break-down of the tip end, which would thereby maintain the tip longevity as well as high, stable energy output. Furthermore, for soft tissue surgery, contact tips should be used only for soft tissue procedures to maintain minimal alteration and contamination of contact surface, which thereby extends the longevity. On the other hand, consideration of the practical irradiation methods to maintain the highenergy output by reducing tip wear may be necessary. In hard tissue treatment, as previous reports suggested ${ }^{40)}$, near-contact mode may be necessary to avoid rapid damage of the contact surface. The difference in ablation efficiency and contact surface alteration between contact and near contact irradiation modes should be clarified by further studies.

The primary focus of this study was the change of the quartz contact surface and energy output reduction during irradiation in relation to different target materials. The degree of degradation and contamination of the tips were considered to be different depending on the tip shape; for example, a thin or tapered end tip should be more easily fractured during irradiation. Thus, the damages of different types of tips should also be compared in future studies.

\section{CONCLUSION}

The results of the present study demonstrated that energy output reduction is inevitable for quartz tips following contact usage. The rate of energy output reduction and the degree of surface alteration/ contamination is influenced by the targeting tissue, temperature elevation of the tip as well as the use of 
water spray during irradiation. During irradiation without water spray, distinct temperature elevation of tips occurred but water spray minimized the elevation. The energy output decrease potentially occurred due to diffusion or blocking of the applied laser beam by the irregular surface as well as ablated or evaporated target material attached to the tip surface during irradiation.

\section{ACKNOWLEDGMENTS}

We wish to thank Drs. Sayaka KATAGIRI, Kenichiro EJIRI, Masanori SAWABE, Mayumi OGITA, and Masahiro NODA at the Department of Periodontology, TMDU, and Mrs. Yoshihide OKAGAMI, Akihito HONGO, and Kazunori HAMADA at J. Morita Mfg, for their kind technical advice and support for this study. We also appreciate Nippon Avionics, for their kind support for allowing the use of an infrared thermal imaging system. This work was supported by JSPS KAKENHI Grant Number 25463212 for A.A..

\section{REFERENCES}

1) Aoki A, Sasaki KM, Watanabe H, Ishikawa I. Lasers in nonsurgical periodontal therapy. Periodontol 2000 2004; 36: 59-97.

2) Ishikawa I, Aoki A, Takasaki AA, Mizutani K, Sasaki KM, Izumi Y. Application of lasers in periodontics: true innovation or myth? Periodontol 2000 2009; 50: 90-126.

3) Izumi Y, Aoki A, Yamada Y, Kobayashi H, Iwata T, Akizuki T, Suda T, Nakamura S, Wara-Aswapati N, Ueda M, Ishikawa I. Current and future periodontal tissue engineering. Periodontol 2000 2011; 56: 166-187.

4) Hale GM, Querry MR. Optical constants of water in the 200$\mathrm{nm}$ to $200-\mu \mathrm{m}$ wavelength region. Appl Opt 1973; 12: 555563.

5) Wigdor HA, Walsh JT, Jr., Featherstone JD, Visuri SR, Fried D, Waldvogel JL. Lasers in dentistry. Lasers Surg Med 1995; 16: 103-133.

6) Keller U, Hibst R, Geurtsen W, Schilke R, Heidemann D, Klaiber B, Raab WH. Erbium:YAG laser application in caries therapy. Evaluation of patient perception and acceptance. J Dent 1998; 26: 649-656.

7) Ando Y, Aoki A, Watanabe H, Ishikawa I. Bactericidal effect of erbium YAG laser on periodontopathic bacteria. Lasers Surg Med 1996; 19: 190-200.

8) Yamaguchi H, Kobayashi K, Osada R, Sakuraba E-i, Nomura T, Arai T, Nakamura J. Effects of Irradiation of an Erbium: YAG Laser on Root Surfaces. J Periodontol 1997; 68: 11511155 .

9) Folwaczny M, Mehl A, Aggstaller H, Hickel R. Antimicrobial effects of $2.94 \mu \mathrm{m}$ Er:YAG laser radiation on root surfaces: an in vitro study. J Clin Periodontol 2002; 29: 73-78.

10) Pourzarandian A, Watanabe H, Ruwanpura SMPM, Aoki A, Ishikawa I. Effect of low-level Er:YAG laser irradiation on cultured human gingival fibroblasts. J Periodontol 2005; 76: 187-193.

11) Akiyama F, Aoki A, Miura-Uchiyama M, Sasaki K, Ichinose S, Umeda M, Ishikawa I, Izumi Y. In vitro studies of the ablation mechanism of periodontopathic bacteria and decontamination effect on periodontally diseased root surfaces by erbium:yttrium-aluminum-garnet laser. Lasers Med Sci 2011; 26: 193-204.

12) Ejiri K, Aoki A, Yamaguchi Y, Ohshima M, Izumi Y. Highfrequency low-level diode laser irradiation promotes proliferation and migration of primary cultured human gingival epithelial cells. Lasers Med Sci 2014; 29: 1339-1347.

13) Hibst R, Keller U. Experimental studies of the application of the Er:YAG laser on dental hard substances: I. Measurement of the ablation rate. Lasers Surg Med 1989; 9: 338-344.

14) Keller U, Hibst R. Effects of Er:YAG laser in caries treatment: a clinical pilot study. Lasers Surg Med 1997; 20: 32-38.

15) Aoki A, Ishikawa I, Yamada T, Otsuki M, Watanabe H, Tagami J, Ando Y, Yamamoto H. Comparison between Er:YAG laser and conventional technique for root caries treatment in vitro. J Dent Res 1998; 77: 1404-1414.

16) Hossain M, Nakamura $Y$, Kimura $Y$, Yamada $Y$, Ito M, Matsumoto K. Caries-preventive effect of Er:YAG laser irradiation with or without water mist. J Clin Laser Med Surg 2000; 18: 61-65.

17) Flury S, Koch T, Peutzfeldt A, Lussi A. Micromorphology and adhesive performance of Er:YAG laser-treated dentin of primary teeth. Lasers Med Sci 2012; 27: 529-535.

18) Baghalian A, Nakhjavani $Y$, Hooshmand T, Motahhary $P$, Bahramian H. Microleakage of Er:YAG laser and dental bur prepared cavities in primary teeth restored with different adhesive restorative materials. Lasers Med Sci 2013; 28: 1453-1460.

19) Angiero F, Benedicenti S, Signore A, Parker S, Crippa R. Apicoectomies with the erbium laser: a complementary technique for retrograde endodontic treatment. Photomed Laser Surg 2011; 29: 845-849.

20) Lietzau M, Smeets R, Hanken H, Heiland M, Apel C. Apicoectomy using Er:YAG laser in association with microscope: a comparative retrospective investigation. Photom Laser Surg 2013; 31: 110-115.

21) Marques A, Gerbi MM, dos Santos J, Noia M, Oliveira P, Junior A, Zanin FA, Pinheiro AL. Influence of the parameters of the Er:YAG laser on the apical sealing of apicectomized teeth. Lasers Med Sci 2011; 26: 433-438.

22) Aoki A, Ando Y, Watanabe H, Ishikawa I. In vitro studies on laser scaling of subgingival calculus with an Erbium:YAG laser. J Periodontol 1994; 65: 1097-1106.

23) Schwarz F, Sculean A, Berakdar M, Georg T, Reich E, Becker J. Periodontal treatment with an Er:YAG laser or scaling and root planing. A 2-year follow-up split-mouth study. J Periodontol 2003; 74: 590-596.

24) Schwarz F, Aoki A, Sculean A, Georg T, Scherbaum W, Becker J. In vivo effects of an Er:YAG Laser, an ultrasonic system and scaling and root planing on the biocompatibility of periodontally diseased root surfaces in cultures of human PDL fibroblasts. Lasers Surg Med 2003; 33: 140-147.

25) Sculean A, Schwarz F, Berakdar M, Romanos GE, Arweiler NB, Becker J. Periodontal treatment with an Er:YAG laser compared to ultrasonicInstrumentation: a pilot study. J Periodontol 2004; 75: 966-973.

26) Aoki A, Miura M, Akiyama F, Nakagawa N, Tanaka J, Oda S, Watanabe H, Ishikawa I. In vitro evaluation of Er:YAG laser scaling of subgingival calculus in comparison with ultrasonic scaling. J Periodontal Res 2000; 35: 266-277.

27) Schwarz F, Aoki A, Becker J, Sculean A. Laser application in non-surgical periodontal therapy: a systematic review. J Clin Periodontol 2008; 35: 29-44.

28) Mizutani K, Aoki A, Takasaki AA, Kinoshita A, Hayashi C, Oda S, Ishikawa I. Periodontal tissue healing following flap surgery using an Er:YAG laser in dogs. Lasers Surg Med 2006; 38: 314-324.

29) Schwarz F, Sculean A, Georg T, Reich E. Periodontal treatment with an Er:YAG laser compared to scaling and root planing. A controlled clinical study. J Periodontol 2001; 72: 361-367.

30) Sculean A, Schwarz F, Berakdar M, Windisch P, Arweiler $\mathrm{NB}$, Romanos GE. Healing of intrabony defects following surgical treatment with or without an Er : YAG laser. J Clin Periodontol 2004; 31: 604-608. 
31) Panduric DG, Bago I, Katanec D, Zabkar J, Miletic I, Anic I. Comparison of Er:YAG laser and surgical drill for osteotomy in oral surgery: An experimental study. J Oral Maxillofac Surg 2012; 70: 2515-2521.

32) Schwarz F, Rothamel D, Sculean A, Georg T, Scherbaum W, Becker F. Effects of an Er : YAG laser and the Vector ${ }^{\circledR}$ ultrasonic system on the biocompatibility of titanium implants in cultures of human osteoblast-like cells. Clin Oral Implants Res 2003; 14: 784-792.

33) Schwarz F, Bieling K, Bonsmann M, Latz T, Becker J. Nonsurgical treatment of moderate and advanced periimplantitis lesions: a controlled clinical study. Clin Oral Investig 2006; 10: 279-288.

34) Takasaki AA, Aoki A, Mizutani K, Schwarz F, Sculean A, Wang CY, Koshy G, Romanos G, Ishikawa I, Izumi Y. Application of antimicrobial photodynamic therapy in periodontal and periimplant diseases. Periodontol 2000 2009; 51: 109-140.

35) Taniguchi Y, Aoki A, Mizutani K, Takeuchi Y, Ichinose S, Takasaki AA, Schwarz F, Izumi Y. Optimal Er:YAG laser irradiation parameters for debridement of microstructured fixture surfaces of titanium dental implants. Lasers Med Sci 2013; 28: 1057-1068.

36) Schwarz F, Hegewald A, John G, Sahm N, Becker J. Fouryear follow-up of combined surgical therapy of advanced peri-implantitis evaluating two methods of surface decontamination. J Clin Periodontol 2013; 40: 962-967.

37) Takasaki AA, Aoki A, Mizutani K, Kikuchi S, Oda S, Ishikawa I. Er:YAG laser therapy for peri-implant infection: a histological study. Lasers Med Sci 2007; 22: 143-157.
38) Kim KS, Kim ME, Shin EJ. Irradiation time and ablation rate of enamel in contact and non-contact irradiation with Er:YAG laser. Photomed Laser Surg 2005; 23: 216-218.

39) Eguro T, Maeda T, Ogawa M, Yonemoto K, Tanaka H, Katsuumi I. Electron probe micro-analysis of a contact probe after Er:YAG laser tooth ablation. Dent Mater J 2003; 22: 8086.

40) Eguro T, Aoki A, Maeda T, Takasaki AA, Hasegawa M, Ogawa M, Suzuki T, Yonemoto K, Ishikawa I, Izumi Y, Katsuumi I. Energy output reduction and surface alteration of quartz and sapphire tips following Er:YAG laser contact irradiation for tooth enamel ablation. Lasers Surg Med 2009; 41: 595-604.

41) Yamazaki K, Eguro T, Maeda T, Tanaka H. Output energy changes of quartz contact probe for Er:YAG laser with tooth ablation. Dent Mater J 2003; 22: 292-300.

42) Rosa DS, Aranha AC, Eduardo Cde P, Aoki A. Esthetic treatment of gingival melanin hyperpigmentation with Er:YAG laser: short-term clinical observations and patient follow-up. J Periodontol 2007; 78: 2018-2025.

43) Ishikawa I, Aoki A, Takasaki AA. Potential applications of Erbium:YAG laser in periodontics. J Periodontal Res 2004; 39: 275-285.

44) Jepsen S, Deschner J, Braun A, Schwarz F, Eberhard J. Calculus removal and the prevention of its formation. Periodontol 2000 2011; 55: 167-188.

45) Sasaki KM, Aoki A, Ichinose S, Ishikawa I. Ultrastructural analysis of bone tissue irradiated by Er:YAG Laser. Lasers Surg Med 2002; 31: 322-332. 